\title{
Letzte Badetage
}

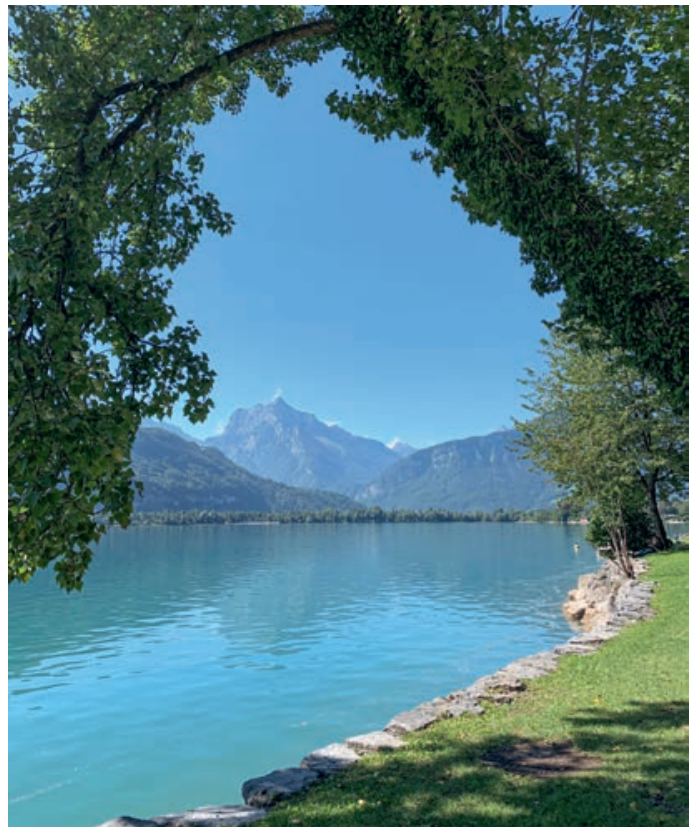

Herbst

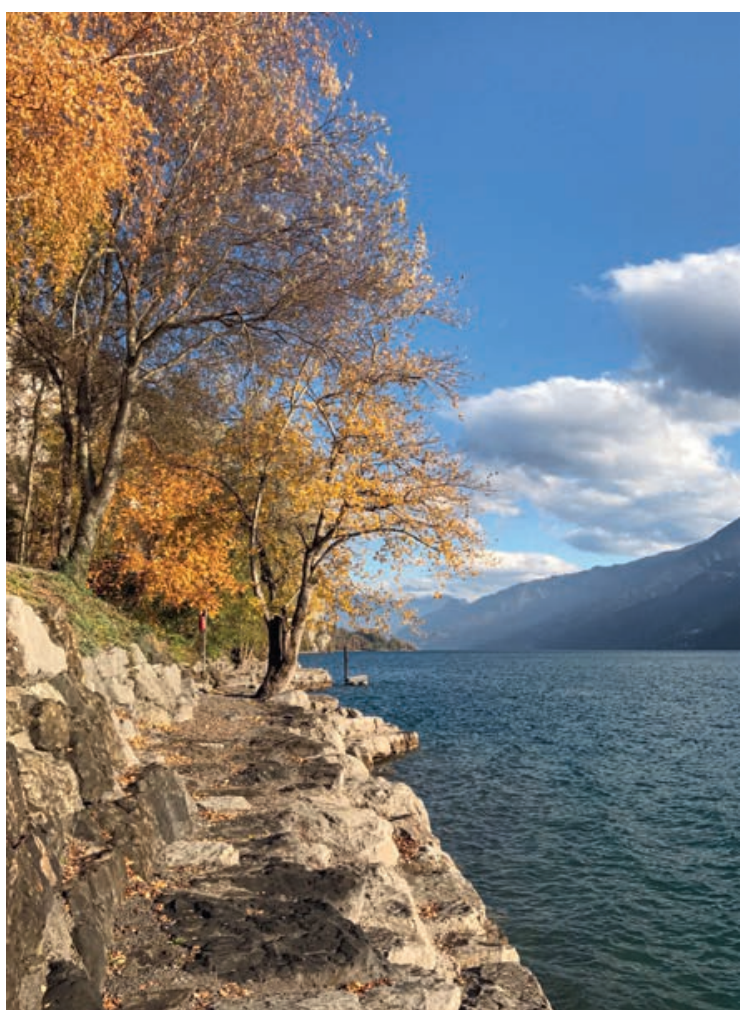

Bildnachweis Hedi Meierhans

\section{Einer der letzten}

Badetage in und am

See. Viel Freude strahlt.

Im Überfluss der

Bläue strahlt Himmel und See Sehnsucht durch die Seele.

Warum ist das Blau So innig berührend? Die Farbe der Seele?

\section{Schneeweisser Falter}

Verschwindet, bevor das $\mathrm{Au}$ ge ihn ganz erhascht.

Heute hat sich der Herbst gnädigst versteckt, doch ein Duft verrät ihn schon.
Der Herbst regnet Blätter auf die Felsbänke herab, zerbrechlich Gold.

Die Menschen überlassen den Blättern den Platz. Da gähnt die Leere.

Kein Vogel regt sich Kein Kindergeschrei ertönt Das Ufer verwaist.

Der Bäume fallend Gold erzählt vom Aufleuchten Der Vergänglichkeit.

Ein goldenes Blatt Fällt mir auf den Kopf. Ich bin Vom Herbst gezeichnet.

Ich sterbe einen Blattfall lang, Verwandlung tropft Sanft in die Seele. 